\title{
Luce Marchal-Albert, La dédicace du De Philologia (1532) de Guillaume Budé
}

\section{Filippo Fonio}

\section{(2) OpenEdition}

1 Journals

\section{Edizione digitale}

URL: http://journals.openedition.org/studifrancesi/30043

DOI: 10.4000/studifrancesi.30043

ISSN: 2421-5856

\section{Editore}

Rosenberg \& Sellier

\section{Edizione cartacea}

Data di pubblicazione: 1 avril 2006

Paginazione: 140

ISSN: 0039-2944

\section{Notizia bibliografica digitale}

Filippo Fonio, «Luce Marchal-Albert, La dédicace du De Philologia (1532) de Guillaume Budé», Studi Francesi [Online], 148 (XLX | I) | 2006, online dal 30 novembre 2015, consultato il 19 avril 2021. URL: http://journals.openedition.org/studifrancesi/30043; DOI: https://doi.org/10.4000/studifrancesi. 30043

Questo documento è stato generato automaticamente il 19 avril 2021.

\section{(c)}

Studi Francesi è distribuita con Licenza Creative Commons Attribuzione - Non commerciale - Non opere derivate 4.0 Internazionale. 


\title{
Luce Marchal-Albert, La dédicace du De Philologia (1532) de Guillaume Budé
}

\author{
Filippo Fonio
}

\section{NOTIZIA}

LUCE MARCHAL-ALBERT, La dédicace du De Philologia (1532) de Guillaume Budé, «Bibliothèque d'Humanisme et Renaissance», LXVII, 1 (2005), pp. 109-120.

1 Le considerazioni proposte dalla studiosa in merito all'epistola dedicatoria al De Philologia di Budé offrono un'interpretazione dello scritto nell'ottica degli appelli dell'umanista al re e alla corte per la creazione di un collège des Muses. La lettera è indirizzata ai principi Henri d'Orléans e Charles d'Angoulême, secondo e terzogenito di François I, sovrano nel cui mecenatismo e amore per le humanae litterae gli umanisti nutrivano buone speranze. La ragione di una dedica non rivolta al sovrano in persona, né al Delfino, da parte di un intellettuale come Budé, attento alle dinamiche tra potere e cultura, è probabilmente da ricondursi alla figura del precettore dei due principi, l'umanista italiano Benedetto Tagliacarne, detto Teocrene. Nell'indirizzarsi ai protetti di Teocrene, il quale godeva di grande considerazione a corte, Budé tenta di lanciare un appello affinché gli umanisti dell'entourage del re si mobilitino per indurre François I a fondare un'istituzione culturale più soddisfacente del neonato Collège des Lecteurs Royaux (poi Collège de France). 